\title{
Back To Class Warfare: The Rhetoric Of Mitt Romney
}

David Depew

Professor Emeritus, Department of Communication

Studies

University of Iowa, Iowa City, IA USA

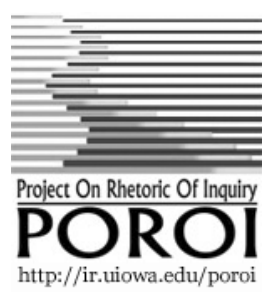

As Marx predicted, capitalism collapsed and weak liberal democratic governments collapsed with it. This happened in the 1930s. After World War II Humpty Dumpty was put back together again in a way that rendered the notion of class conflict, which had been on everyone's tongues for decades, rhetorically inaccessible in political discourse. Everyone began to identify as middle class. The previously marginalized American right wing rose to its current prominence because Ronald Reagan relentlessly engaged in happy talk about the benefits to all of transferring wealth to the already wealthy. It would be morning in America. The Bushes echoed him.

What is striking about Mitt Romney is that he is utterly deaf to rhetorical pieties that put us all in the same class. He lives in a $19^{\text {th }}$ century political imaginary. There are for him, as there were then, two kinds of poor, deserving and undeserving. Together they equal the infamous " $47 \%$."

The deserving poor are the ones Jesus talked about when he said, "The poor you will always have with you" (Matthew 26: 11), suggesting that he might not have considered himself poor, presumably because he could always build houses or go fishing with his disciples to turn a drachma. I $\mathrm{f}$ the system of poor relief, as it was called in Dickensian times, needs fixing Romney says he will fix it. He envisions, it seems, a mix of private, largely religious, and public assistance on the basis of demonstrated dire straits.

The undeserving poor, by contrast, are in Romney's world what used to be called "able bodied men" who shirk their responsibilities. Romney suspects they think of themselves the way Elisa Doolittle's father did in My Fair Lady: as a "victim of middle class morality" with its ridiculous insistence on the Protestant work ethic and Victorian chastity.

My guess is that Romney thinks about 5\% deserve our charity. The undeserving remaining $42 \%$ lumps together an assorted lot. One chunk are working families with children who pay no federal income tax-they pay plenty of other taxes, many regressive-because their salaries are too small to be taxable. How did this happen? Easy. Republican congressmen helped Democrats pass earned income tax credits and other such programs because they wanted to bring home the bacon but were afraid to implicate themselves in raising tax rates.

Another chunk of the $42 \%$ are retired people. Since Romney considers Medicare and Social Security forms of the dole, he has lowered 
his own cognitive dissonance by imagining that recipients of these programs consider themselves entitled to these goodies for reasons very like those of Elisa Doolittle's dad. He may admit they paid into these programs during their working lives. But behind the idea of vouchers may be that you are entitled to what you put in, perhaps with interest, and to nothing else.

Romney thinks that the $47 \%$ will never vote for him because he imputes to them an implausibly high degree of awareness of what he is up to. Not for him the conventional wisdom that the American working class votes against its own interests because it mistakenly believes that the oligarchs support its moral issues. No, for Romney the $47 \%$ can count as well as he can and figure they will make out like bandits under the Democrats.

What about the other 53\%? The 1\% among whom Romney himself lives, moves, and has his being-beneficiaries of the same kind of finance capitalism that did in the world economy in the 1930s--are to his mind the good old entrepreneurial American middle class who built this country. Their ideal, self-reliant society crumbled in the face of a post War consensus that institutionalized the New Deal and the Great Society. But Romney is sure that he and other Republicans, such as his running mate Paul Ryan, can build Jerusalem again when they have rolled back Roosevelt's and Johnson's handiwork. This they intend to do.

Romney's math is interesting. Oddly, he uses the $\$ 250,000$ figure at which President Obama proposes to steepen the marginal tax rate as a class demarcator. "Middle income is \$200,000 to \$250,000 and less," Romney told George Stephanopolous. But not much less. In saying this he was explicitly denying Stephanopoulos's surmise that he was thinking of $\$ 100,000$ as middle income. Obama, whose rhetoric draws on the conventional myth that we are all in the middle class, or with the right public policies might be, does no such thing.

Romney's way of figuring class membership certainly reflects his personal situation as a beneficiary of finance capitalism. He made $\$ 14,000,000$ in 2011 without lifting a finger, so $\$ 200,000$ must look pretty cheesy to him. But it is also consistent with writing off $47 \%$ of the population as morally corrupted by the New Deal. Suppose the enterprising middle class settles around $\$ 200,000$. In that case, it will be easy to find $47 \%$ who, because they make at most a measly $\$ 100,000$, might feel aggrieved by the very existence of Romney and the people he was talking to when he did these calculations. So it is easy to imagine why he might think they would feel entitled to grab everything they can get from the government. Mitt's argument thus becomes a self-sealing one. It's hard to crack its logic once it gets going.

In short, Romney imagines the $47 \%$ as envious and resentful. In the real world, however, it just so happens that median family income is about $\$ 50,000$. People in this income range are not salaried but hourly workers. But as interviews with Barbara Ehrenreich show, many people in this situation reveal, by their palpable fear of falling out of it, a solidly middle class sense of self. Some might feel aggrieved or entitled. After all, they are constantly being nickeled and dimed, as Ehrenreich puts it. 
But most feel grateful for whatever programs come their way that help them stay out of the pit of poverty--work opportunities, health care, child support, skills training, tuition tax credits, food stamps and so forth. It was on the perception that you can separate the cheaters and chiselers who no doubt do exist - from people who want to work but need help that Bill Clinton's reform of the work/welfare relation was predicated. Its success tends to confirm its basis in reality.

Where, then, are Romney's resentful 47\%? Mostly, I think, in his head. If Romney sounds like the Man From The $19^{\text {th }}$ Century it is because he is. He sees the political and social landscape in terms of class interest, class identity, and class conflict.

It is often said that this is an important election. This perception has to do with more than who will control Congress and the Supreme Court, important as these are. It is also significant because of what will happen now that the shared fiction about class harmony that Reagan co-opted from FDR has worn thin enough to see through.

If you want to know what the landscape will look like after the election, I suggest you get your fill of American political speeches and punditry from the 1880 os to about 1940. No matter who wins in 2012, you will be taking yourself back to the future. 